Yayınlayan: Ankara Üniversitesi KASAUM

Adres: Kadın Sorunları Araştırma ve Uygulama Merkezi, Cebeci 06590 Ankara

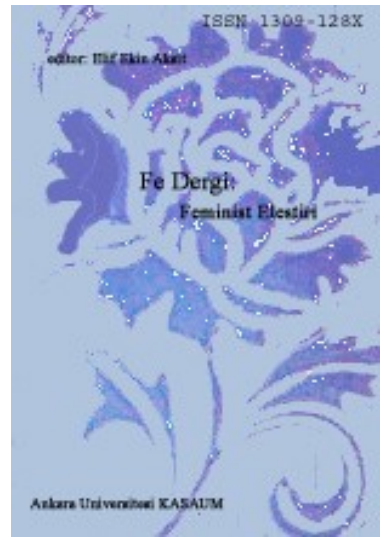

Fe Dergi: Feminist Eleştiri Cilt 2 Sayı 2

Erişim bilgileri, makale sunumu ve ayrıntılar için:

http://cins.ankara.edu.tr/

Osmanlı Kadın Dergileri ve Erkekler Dünyası Dergisi

Mithat Kutlar

Çevrimiçi yayına başlama tarihi: 20 Aralık 2010

Bu makaleyi alıntılamak için: Mithat Kutlar, "Osmanlı Kadın Dergileri içinde Erkekler Dünyası Dergisi," Fe Dergi 2, no. 2 (2010):1-15.

URL: http://cins.ankara.edu.tr/nali.html

$\mathrm{Bu}$ eser akademik faaliyetlerde ve referans verilerek kullanılabilir. Hiçbir şekilde izin alınmaksızın çoğaltılamaz. 
Osmanlı Kadın Dergileri içinde Erkekler Dünyası Dergisi

\section{Mithat Kutlar*}

Kadın sorunu yalnızca Osmanlıda değil dünyanın her yerinde temel bir toplumsal sorun olagelmiştir. Osmanlı kadınları bu sorunun çözümünde erkeklerin dayanışmasını önemsemişler, Osmanlı erkekleri de kimi zaman modernist korumacı söylemin içinden, kimi zaman da dışına çıkarak onlara destek vermeye çalışmışlardır. Örneğin Osmanlı kadın hareketiyle beraber anılan Kadınlar Dünyası gazetesini çıkaran Ulviye Mevlan'ın eşi Mevlanzade Rıfat kadın hareketlerinin güç kazandığı tüm ülkelerde, kadın hareketlerinin erkekler tarafindan da desteklendiğini vurgulamış; buna bağlı olarak kadın ve erkeğin birlikte mücadele etmesinin önemine vurgu yapmıştır. Bu makale, Mevlanzade Rıfat'ı, dönemin erkek aydınlarının açılımsızlı̆̆ına düşmüş ve bazı geleneksel kadın rollerini korumaktan yana fikirler beyan etmiş olsa da Osmanlı feminist yazınına yaptı̆̆ı önemli katkılarıla öne çıkan şahsiyetlerden biri olarak anlatacaktır.

Anahtar sözcükler: Mevlanzade Rıfat, Erkekler Dünyası, Osmanlı kadın hareketi, evlilik, dergiler

\section{Men's World journal among Ottoman women's journals}

Women's problems have been a major social problem not only in the Ottoman empire but also worldwide. Ottoman women have seen solidarity with men as a part of the solution for this problem. Ottoman men, alternatively, have complied with this vision sometimes from within a modernist, paternal-protective discourse and sometimes by trying to challenge this discourse. Mevlanzade Rlfat, who was the husband of a woman who published the Women's World -the journal that has been synonymous with Ottoman women's movement- Ulviye Mevlan, was one of these men. He emphasized that in order for women's movement to be empowered, men should support the movement, and that this was the case in all countries where the movement has excelled. This article introduces Mevlanzade Rifat as one of the male characters who contributed to Ottoman feminist media even though he struggled with the dilemmas of the male entelegensia of his time.

Key words: Mevlanzade Rlfat, Men's World, Ottoman women's movement, marriage, media

\section{Giriş}

Meşrutiyetle birlikte Osmanlı toplumunda, birçok konuda olduğu gibi yazın hayatında da serbestleşme görülür. $\mathrm{Bu}$ serbestlik ortamında gelişen önemli hareketlerden biri de kadın hareketidir. Kadın hareketinin, özellikle İstanbul merkez başta olmak üzere çevre şehirlerde etkileri görülür. Bu etki özellikle kadın yazınının ortaya çıkmasına neden olur. Bu durum, kısa zaman içinde kadın yazınının da gelişimini sağladı. Avrupa'da olduğu gibi Osmanlıda da kadın-erkek arasındaki sosyal ve kültürel egemenlik ilişkilerini tartışmaya açan Kadın hareketi, çok geçmeden, kadınların gayretiyle de olsa erkek aydınlar tarafından da destek görür. O dönemin erkek yazarlarının, kadınlar için öngördüğü destek daha çok iyi bir eş olma veya annelik rollerini daha doğru bir şekilde ifa etme noktasında olsa da, bu destek zamanla daha feminen bakış açılarına doğru evirilebilmiștir. Kadın hareketine yakın duran ve desteğini sunan pek çok önemli aydın ${ }^{1}$ olduğunu da belirtmek gerekir. Bu aydınların birçoğu Osmanlı toplumunda kadın hukukuna ve kadınların sosyal haklarına dair fikirlerini eserlerinde işlediği gibi bazıları da kadın mücadelesine doğrudan katkı sunmak amacıyla dergi çıkarmayı tercih etmiştir. Bu noktada, gazete çıkararak kadınların toplumsal mücadelesine katkı sunmaya çalışmış aydınlardan biri de Ulviye Mevlan'ın² eşi ve aynı zamanda sözkonusu çalışmamızın konusu olan Mevlanzade Rıfat'tır.

Mevlanzade Rıfat'ın bir sayı ile sinırlı kalan “Erkekler Dünyası” adlı kadın dergisi, kadın sorununa erkek penceresinden bakmayı seçen ve kadın hareketine destek amacını taşır. Meşrutiyet döneminde kadın meselesi karşısında erkek aydınların tavrı genel olarak iki türlü olmuştur. Gelenekçi veya modernleşmeci olan bu erkek aydınlardan modernleşmecileri ise kadın meselesine sadece düşünceleriyle katkı sunan dayanışmacı

\footnotetext{
* Avesta Yayınlar1.
} 
erkekler ${ }^{1}$ ile bunun yanı sıra eylemleriyle de katkı sunan aktivist erkek $^{3}$ aydınlar olarak ayırmak mümkündür. Burada şunu söylemek gerekir ki modernleşmecilerin kadın meselesinde durdukları fikri pozisyon, kendilerini gelenekçi erkek aydınlardan ayrıştırma ve farklı bir perspektife oturtma işlevini de içerir. Her iki tarafın da tavrını; öncelikle sıradan vatandaş olan erkeklere karşı sonra da kendi aralarında öne çıkardıkları bir hiyerarşik erkeklik mücadelesi/tutumu olarak değerlendirebiliriz. Bu erkeklik girişimlerini, son kerte de ise dönemin kadın hareketine kendini olumlayan bir erkeklik çabası olduğunu belirtmek gerekir. Çalışmamızda bu bağlamda değerlendirilecek bir erkeklik portresi olarak Mevlânzâde Rıfat'ı kısaca tanıtmaya, sonra da çıkardığı dergi vesilesiyle sınırlı da olsa kadın sorununa ilişkin fikirlerine değinmeye çalışacağız.

\section{Mevlânzâde Rıfat (1869-1930)}

Osmanlının önemli entelektüellerinden Mevlânzâde Rıfat Süleymaniye Kürtlerindendir. Uzun yıllarını İstanbul'da geçiren Kürt aydını, çıkardığı Serbesti adlı gazete aracıllğıyla daha çok bir gazeteci olarak tanınmışıtır. İttihat ve Terakki'nin iktidarda olduğu yıllarda değişik gazetelerde İttihat ve Terakki karşıtı eleştirel yazılar kaleme alan Mevlânzâde Rıfat, bu uğurda uzun sürgün yıllarını göze alan, birkaç kez saldırılara dahi hedef olan mücadeleci gazetecilerden birisidir. İttihat ve Terakki partisinin oligarşik iktidarından rahatsızlık duyan Rıfat, aynı zamanda ittihatçı hükümetin, çok sesliliği bastıran tutumunu da sert bir dille eleştirir. $\mathrm{Bu}$ nedenle ittihatçıların fişlediği, kara listeye aldığı biri olur. Ölüm tehditlerine maruz kalır. Hatta İttihat ve Terakki karşıtı fikirleriyle tanınan Serbesti gazetesinin başyazarı Hasan Fehmi'nin, Mevlânzâde Rıfat sanılarak öldürüldüğü belirtilir. ${ }^{4}$

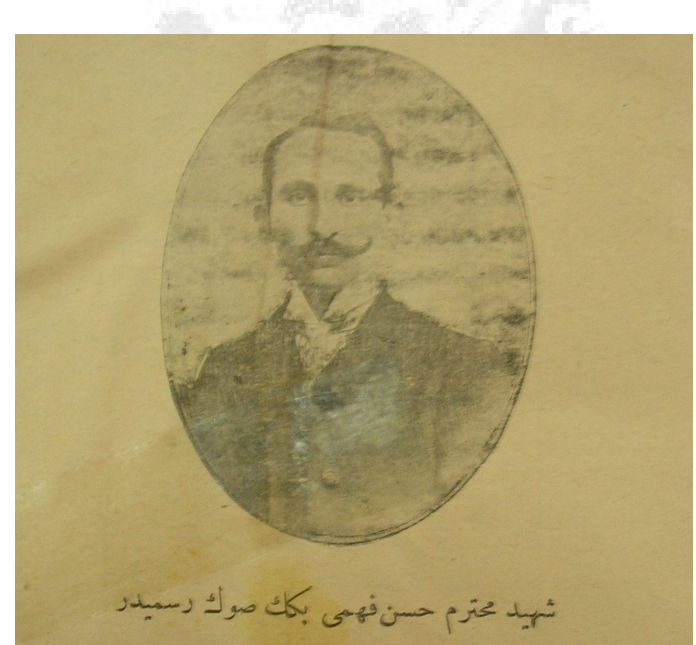

“Şehid muhterem Hasan Fehmi beyin son resmidir”: Serbestî'den

Meşrutiyet öncesinde Sultan Reşat'ın taraftarı olduğu öne sürülerek 12 y1l hapis ve sürgün cezasına çarptırılır, Yemen'e sürülür. Meşrutiyet'in ilan edilmesiyle İstanbul'a dönen Mevlânzâde Rıfat hislerini "gerçekten bir büyük bayram olan 23 Temmuz 1908 tarihi yüceltilmeye layıktır. Bu muazzez günün hayat veren rüzgârı, bizi de binlerce siyasi mağdur gibi tam 12 sene hapisten hapse, sürgünden sürgüne sürüklendikten sonra son sürgün yerimiz olan Yemen'in San'a şehrindeki sefil yaşantımızdan kurtardı" şeklinde ifade etmiştir. İstanbul'a döndüğünde arkadaşlarıyla birlikte önce Hukuk-1 Umumiye gazetesinin yönetimini ele alır, sonra da arkadaşı Hasan Fehmi ile birlikte Serbesti gazetesini çıarır. ${ }^{2}$ Bu kez de 31 Mart vakası meydana gelir, olayda etkisi olduğu nedeniyle ikinci kez 10 yıl sürgün cezasına çarptırılır. ${ }^{5}$

\footnotetext{
${ }^{1}$ Abdullah Cevdet, Rıza Tevfik, Selahattin Asım, Ahmet Cevat, Celal Nuri, Ziya Gökalp, Baha Tevfik bunlar arasında gösterilebilir.

${ }_{2}^{2}$ Mevlanzade Rifat. Mevlanzade Rlfat'in Anıları, İstanbul: Arma yayınları, 1992, 11-12.
} 


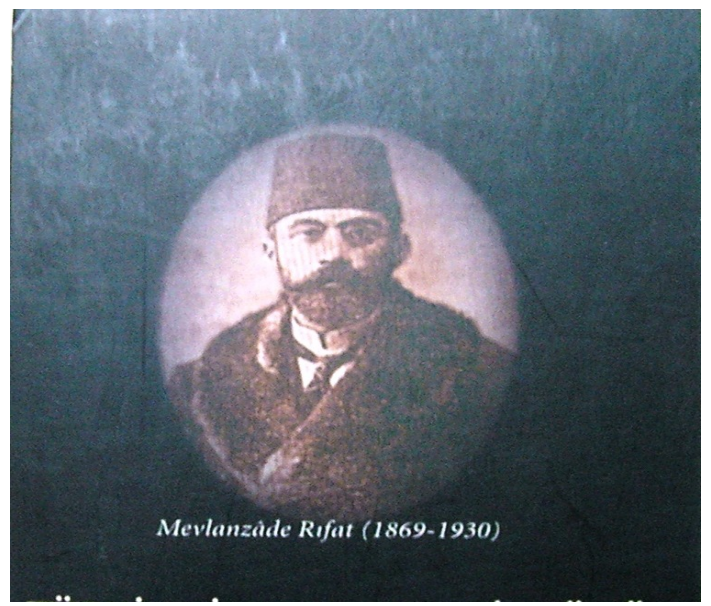

Mevlanzade Rıfat 31 Mart vakasının gerçekleşmesinde rolü olduğunu düşünenlere karşı da konuşmaktan kendini alıkoymaz ve olayın tertipçilerini de şiddetle eleştirir: "Askeri ayaklanmayı hazırlayıp düzenleyenler, alçak ve yüreksiz oldukları kadar ihtilal kurallarından da habersizdiler. İhtilaller hakkında okudukları bilgileri de eksikti. İhtilalin nasıl idare edileceğini bilmiyorlardı. İşte böyle miskinler 31 Mart ayaklanmasının tertipçisiydiler. Her biri kendisini bir ihtilal kahramanı sayıyordu. Tehlikelerle dolu siyaset sahnesinde aktörlük yapmaya kalkmışlardı. Netice ne oldu? Utanç!... Boş yere dökülen kan..." 6 Öte yandan Mevlanzada Rıfat, merkezi yönetim biçiminin ve tek merkezden toplumun tamamına dayatılan uygulamaların, toplumun her kesimine aynı faydayı sağlamadığını savunmaktadır. Osmanlının merkezi yönetiminin sorunlu olduğunu vurgular ve toplumu oluşturan farklı etnik yapıların ihtiyaçlarına artık cevap vermediğini ifade etmektedir. Yönetim teorisi konusunda, dönemin fikir adamlarından Prens Sabahattin'in yönetim anlayışı olan Âdem-i Merkeziyetçi teorisine yakınlığıyla da biliniyordu. Âdem-i Merkeziyetçi yönetimin Osmanlı halkları -çok etnikli yapısı nedeniyle- için ideal bir yönetim biçimi olduğunu savunan Mevlanzade Rıfat gerekçe olarak şunları söyler: "Evet biz görüyorduk ki Yakova'da bulunan bir Arnavut ile Necd'de bulunan bir Vahhabi'nin; İstanbul'da bulunan efendi ile Yemen'de bulunan bir Zeydi'nin; Selanik'te bulunan bir Yahudi'yle Hicaz'da bulunan bir Bedevi'nin; Konya'da bulunan bir Türk ile Süleymaniye'de bulunan bir Kürt'ün; Adalar'da bulunan bir Rum'la Van'da bulunan bir Ermeni'nin sosyal ve ruhsal durumu, gelenek ve görenekleri bir değildir. Merkezi yönetim, bir kanun hükmünü bu çeşitli unsurlar üzerinde aynı etki ve kuvvetle uygulama kabiliyetine sahip değildir. Evet biz, kanunların, kavimlerin örf ve adetleri göz önüne alınarak düzenlenmesini ve bütün unsurların yalnız 'Osmanlı' yüce adı altında köklü surette bağlanarak birleştirilmesini ve bu suretle öteden beri var olan kavimler arası anlaşmazlıkların giderilmesini istiyor, kavimlerin birliğine göre vilayet dairelerinin genişletilmesi ona göre de kanunlar düzenlenmesini esas buluyorduk." 7

Bazı kaynaklarda ise kendisinden zaman zaman söz edilen Mevlanzade Rıfat'ın, Şerif Paşa'nın İttihatçılara karşı yürüttüğ̈̈ mücadeleyi destekleyerek, Onunla birlikte bazı örgütlenme ve yayın çalışmalarını yürüttüğü belirtilmektedir. Mevlanzade Rıfat, Şerif Paşa'nın 1909 yılında kurduğu Islahatı Esasiye-i Osmaniye Fırkası'nın kurucuları arasında yer alır. 1909 yılında yurtdışına çıkmak zorunda kalan Mevlanzade Rıfat, burada Şerif Paşa'nın maddi desteğiyle daha önceleri İstanbul'da yayımlanan Serbesti gazetesini yeniden Paris'te yayımlar. Bu gelişme ile Şerif Paşa'nın prestijini gazete aracılığıyla medya aracılığıyla canlı tutmak istediği söylenebilir. Kanımca Şerif Paşa, bu prestijin oluşumundaki Mevlanzade Rıfat'ın rolünü tam olarak görememiştir. Çünkü belli aralıklarla çıkan Serbesti gazetesini Avrupa'da çıkarma planları, Şerif Paşa ve Mevlanzade Rıfat arasında baş gösteren anlaşmazlık nedeniyle fazla uzun sürmez, başarısızlığa uğrar. Anlaşmazlık alacak verecek ilişskisi konusundadır. $\mathrm{Bu}$ yıllarda yurtdışında zor ortamlarda yaşayan muhaliflerin ekonomik sıkıntıları kendilerini güç durumda bırakır. Mevlanzade Rıfat, anılarında Şerif Paşa'nın kardeşi Fuat Paşa'dan alınan 800 liralık bir borca da değinir. Mevlanzade Rıfat, anılarında Şerif Paşa ile olan anlaşmazlığı konusunu Bilânço adlı kitabında ele aldığını belirtir. ${ }^{8}$ Şerif paşa ile yaşadığı anlaşmazlık sonucu Serbesti gazetesinin Paris ayağı başarısılığa uğrar ve mısıra gider. Mısır hükümeti de kendisine çeşitli zorluklar yaratır ve sınır dışı edilir. Yunanistan'a geçmek zorunda kalan Mevlanzade Rıfat, Atina'da Faruk ve Cihat adlı taş basma gazeteleri çıkarmaya başlar. Meşrutiyetle birlikte İstanbul'a dönen Mevlanzade Rıfat affedilerek, Serbesti gazetesini yeniden yayımlamaya 
devam eder. ${ }^{9}$ Yaşamı boyunca birkaç kez sürgün cezasına çarptırılan Mevlanzade Rıfat, son sürgünü ${ }^{10}$ sırasında yaşama veda eder.

Yazılarında realist tavrıyla da dikkat çekmiştir. Realist ve ödünsüz bir tavır ile doğruları savunmanın bir basın mensubunun temel görevi olduğunu; " matbuatta yani basın dünyasında meslek sahibi olmak isteyenlerin kamuoyuna karşı birçok görevleri vardır. Bütün olayların hakikatini aramak, bulmak ve zamanı geldiğinde de kamu vicdanına arz etmekle yükümlüdürler." sözleriyle vurgulamıştır. ${ }^{11}$

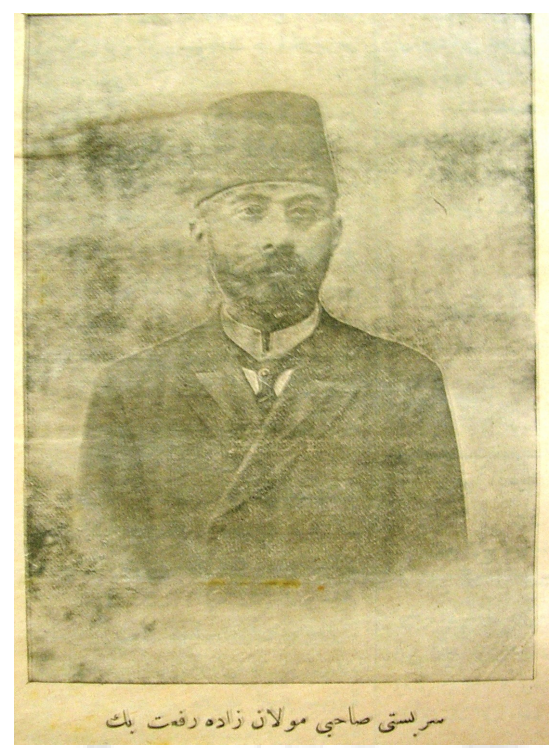

“Serbesti sahibi Mevlanzade Rıfat Bey” serbestî’den

Elbette çok yönlü bir kişiliğe sahip olan Mevlanzade Rıfat'ın kadın hareketine katkı niteliğindeki girişimleri apayrı bir öneme sahiptir. Mevlanzadenin Osmanlı hadın hareketine yaptığı önemli katkılardan biri de Osmanlı ilgili kurumlarına başvurarak Belkıs şevket'in teyyare ile uçuşunu sağlayan girişimleridir. Buna göre o dönemlerde Rus kadın pilotu Tereşkova uzay yolculuğu yapmak cesaretini gösterdiği için tüm Rusya'da ve dünyada kadının itibarını yükseltir. ${ }^{3}$ İşte Ulviye Mevlan, başkanı da olduğu Müdafa-i Hukuk-u Nisvan Cemiyetin'in buna benzer bir icraatta bulunmasını kadınların hem ulusal hem de uluslar arası kamuoyunda seslerini duyurabilmeleri açısından önemli görüyordu. Aynı zamanda Osmanlı kadınlarının gelişen bilim dünyasına seyirci kalmadığı da böylece kanıtlanacaktı. ${ }^{4}$ Isşte Nuriye Ulviye Mevlan da bu neticeyi istiyordu. En sonunda cemiyet üyelerinden Belkıs Şevket hanımefendinin uçağa binmesine karar verilir. Belkıs Şevket hanımefendi uçağa binme isteğini Mevlânzâde Rıfat ve Ahmet Süreyya Bedirhan'ın vekâletinde, ${ }^{5}$ birinci kolordu komutanı olan Cemal Paşa'ya iletir. Cemal Paşa'nın bu isteği kabul etmesi üzerine 18 Teşrin-i Sani 1329 da (18 Kasım 1913) Belkıs Şevket, babasının elini öper ve cemiyet azalarının alkışları arasında; Teyyare Okulu'ndan Fethi Bey adındaki pilot tarafından kullanılan askeri uçakla uçar. ${ }^{6}$ Belkıs Şevket Hanım, Beyoğlu, Pangaltı, Hürriyet-i Ebediye Tepesi, Boğaziçi ve Üsküdar üzerinde uçar. ${ }^{7}$ Büyük bir merasimle Belkıs Şevket Hanım’ın uçağa bindirilmesi ve bu uçuş ile Belkıs Şevket hanımın İstanbul semalarında dolaşması, Avrupa basınında da büyük yankı uyandırır. $\mathrm{Bu}$ uçuş vesilesiyle "kadınlık cesur olmak, vatan-1 mukaddesimizi cesaret kurtarır. Kadınlık ancak cesaretle teali eder" şeklinde beyanlarla Türk kadınlarının da cesaretli olduğu vurgulanır. Diğer yandan kadınların hayata dair tüm sorunlarda olduğu gibi, vatan savunmasında da cesaret ve azimlerinden hiçbir

\footnotetext{
${ }^{3}$ Adile Ayda. Kadın gazetesi. 13 Aralık 1965, 15

${ }^{4}$ Serpil Çakır. Osmanlı kadın hareketi, İstanbul: Metis Yayınları, 1996, 59.

${ }^{5}$ Mevlanzade Rıfat dışındaki şahıs Kürt aydınlanmasında ve Kürt hareketinin başlamasında rol oynamış Bedirhan Bey'in torunu Ahmet Süreya Bedirhan Bey'dir.

${ }^{6}$ Çakır. Osmanlı kadın hareketi, 60.

${ }^{7}$ Bakınız: Kadınlar Dünyası imzasıyla “Belkıs Şevket Hanım Kızımız Uçtu,” Kadınlar Dünyası 119, 23 Teşrini Sani 1329, 2-3 ve Ruşen Zeki. "Bizde Hareket-i Nisvan,” Nevsal-i Milli, İstanbul, 346.
} 
zaman ödün vermeyecekleri gösterilmeye çalışılır. ${ }^{8}$ Meşrutiyete birlikte Osmanlıda kadınlar, bir hukuk mücadelesine başlarken, hâkim kadın erkek ilişkilerinin geleneksel kuruluş biçimlerini de eleştirmeye başlarlar. Kadının toplumsal statüsünün yeniden inşası için yazın hayatında etkili mücadele veren kadın gazeteleri yayınlanır. Bunun yanı sıra erkeklerin de kadınlara dair sık sık yazı yazmaya başladığı bir dönemdir, bu. Mevlânzâde Rıfat da bu sürece bir gazete çıarmakla katkı sunmanın gereğine inanmıştır. Mevlanzade Rıfat kendi döneminde kadınların kurtuluşuna önem veren aydınlardan biridir. Osmanlı kadın hareketi meşrutiyet yıllarında Mevlanzade Rıfat Abdullah Cevdet, Ziya Gökalp gibi aydınların da büyük desteğini kazanır. Mevlanzade Rıfat, erkeklerin bu konudaki sorumluluklarını kendilerine hatırlatmak amacıyla Erkekler Dünyası adlı bir dergi çıkarır. Serpil Çakır, Osmanlı kadın hareketi hakkında yazdığı önemli eserinde bu dergi hakkında "Rifat Mevlan, kadın hukukunu, kadın haklarını savunmuş, bu amaçla Erkekler Dünyası'nı çıkarmıştır"9 demektedir. Mevlânzâde Rıfat, Kadınlar Dünyası ve Erkekler Dünyası arasındaki sosyal uçurumu aşmak ve yakınlaşmayı sağlamak için kadın haklarını savunan bir gazete olan Erkekler Dünyası'nı çıkarmıştır. Bu konuda Rıfat şunları söyler: “Biz dünyada yalnız bir 'İnsanlık Dünyası' görmek isteriz. Bunun için de kadın, erkek bir seviyede olması, her bir umur ve hususta müş̧erek bulunması, iktiza eder. İşte bu maksadın temini için bütün kuvvetimizle çalışacağız. Ümit ederiz ki tabaka-i münevvere; gençlik bize daima müzahir bulunacaktır" Öte yandan Mevalânzâde Rıfat, Erkekler Dünyası'nın amacını ise, "kadınlar dünyası ili Erkekler Dünyası'nı tedrici [yavaş yavaş] olmakla beraber seri adımlarla birbirini takip ederek [yaklaştırma] 'İnsanlar Dünyası'nı vucuda getirmek" olduğunu ifade etmektedir ${ }^{12}$

Mevlanzade Rıfat'ın Osmanlı kültür, siyaset ve yazın hayatındaki rolü büyük olmuştur. Birçok Parti, gazete ve dernek kurmuş olmasına karşın, Mevlanzade'nin hayatıyla ilgili hala yeteri kadar bilgiye ulaşılmış değil. Osmanlı basınında prestijli bir yer edinmiş olan aydının, özellikle ailesi, sürgün hayatı ve özel hayatıyla ilgili bilgilerin yok denecek kadar az oluşu da şaşırtıcıdır. Öte yandan Mevlanzade Rıfat, İkinci Meşrutiyet dönemi sonrasında ağırlık kazanacak, Osmanlı feminist hareketine de katkı sunan önemli Kürt aydınlarındandır. Mevlanzade Rıfat'ın, kadınların toplumdaki talihsiz konumlarının iyi yönde dönüşümüne katkı amacıyla "Erkekler Dünyası" adlı bir dergi çıkardığını daha önce belirtmiştik. Dergi tek sayıyla sınırlı kalmıştır. Söz konusu derginin neden tek sayı ile sınırlı kaldığı ayrı bir çalışma konusu olabilir, fakat biz bu tek sayı vesilesiyle Mevlanzade Rıfat'ın Osmanlı kadın hareketini de ilgilendiren fikirlerine kısaca ele alalım.

\section{Erkekler Dünyası'nın Künyesi}

19 Ocak 1913'te çıkan Gazetenin kapağındaki yazıdan da anlaşılacağı gibi gazete, aydınlık yolda ilerleyen, Osmanlı gençlerine/aydınlarına armağan edilmektedir: "sahaifimiz kadınlığın kadr ü kıymetini ilim, ilim ve fen ve edebin ulviyetini takdir eden münevver Osmanlı gençleri asarına küşadedir" 13

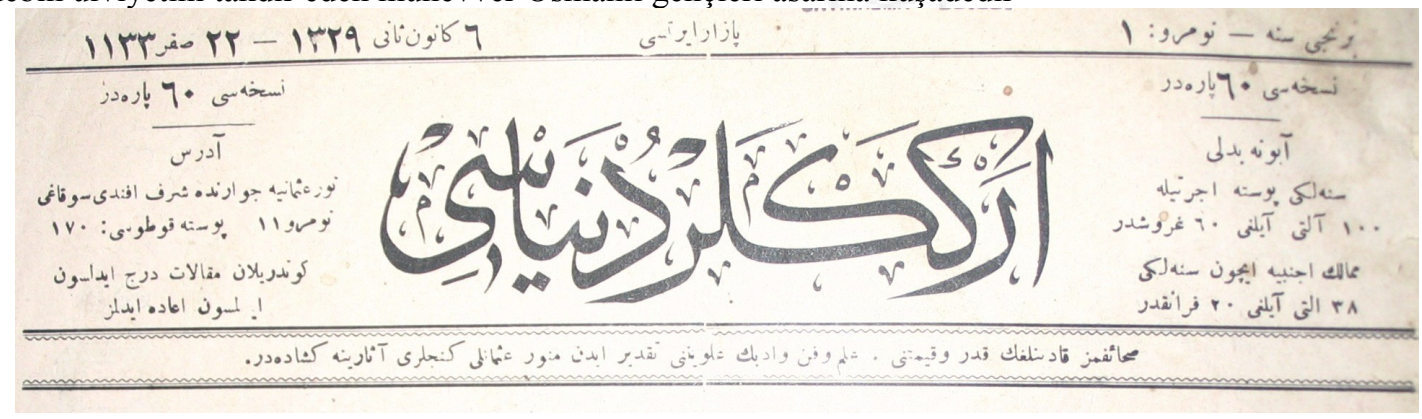

\section{"Erkekler Dünyası"}

Erkekler Dünyası dergisinin bu sayısında, başyazı niteliğindeki “iki söz”(s:2) adlı yazının Mevlanzade Rıfat tarafından yazıldığı, kullanılan üsluptan anlaşılmaktadır. Gazetede İbn-i Azize Sina Raşit’e ait "Tabii düşünelim”(s:3-4) ve İbnüsselim Süleyman’a ait "Şebabet/gençlik”(s:8) adlı yazılar yer almaktadır. Yazarının

\footnotetext{
${ }^{8}$ Kadınlar Dünyası imzasıyla "Belkıs Şevket Hanım Kızımız Uçtu,” Kadınlar Dünyası 119, 23 Teşrini Sani 1329, 3.

${ }^{9}$ Çakır, Serpil. Osmanlı Kadın Hareketi. Metis yay. İstanbul 1996
} 
belirtilmediği yazıların Mevlanzade Rıfat tarafından yazıldığını düşünüyoruz. Çünkü daha önce çıkardığı Serbesti Gazetesi'nde de aynı üslupta yazılmış birçok isimsiz yazının kendisine ait olduğunu tespit ettik. Gazetede yer alan ve yazarları belirtilmemiş yazılar şunlardır: "Mesut bir aile nasıl teşekkül eder(s:5-6)", "Sefahat-1 Sefahatten(s:6-7)", "Gençlerimizin genç kızlarımızı iğfal yolunda takdim etmekte oldukları muaşaka mektuplarından numune(s:7)". Gazetede ayrıca iki ilan sayfası da mevcuttur.

\section{Erkekler Dünyası'nda Kadın Meselesi}

Mevlanzade Rıfat kendi döneminde kadın sorununa kafa yoran sayılı aydınlardan biridir. Osmanlı kadın hareketi meşrutiyetle birlikte Mevlanzade Rıfat, Abdullah Cevdet, Ziya Gökalp gibi önemli aydınların büyük desteğini kazanır. Mevlanzade Rıfat, gazetecilik tecrübesini bu alana da kazandırmak ve kadın cephesine erkekler üzerinden katkı sunmak için bir gazete çıkarır. Kadın sorunlarıyla ilgili olarak erkeklere, sorumluluklarını hatırlatmak amacıyla 'Erkekler Dünyası' adlı dergiyi14 çıkaran Mevlanzade Rıfat, kadın hukukunun, kadın haklarının savunulması gerektiğini; çünkü kadınların toplumsal özne olarak görmezden gelindiğini ifade etmekte ve bu amaçla Erkekler Dünyası'nı çıkardı̆̆ını belirtmektedir. Öte yandan Mevlanzade Rıfat, gazetenin adının Erkekler Dünyası olmasından dolayı yanlış anlaşılmaması gerektiğini dile getirerek, sanıldığının aksine kadınların toplumsal yaşama eklemlenmesine vurgu yapan bir gazete olduklarına değinir: "Erkekler Dünyası, saha-i matbuata atıldı ve vazifesine başladı. İhtimal ki bu isimden, Erkekler Dünyası isminden (Kadınlar Dünyası'na) kadınların cihad-ı meşruane, zad bir mevki, zad bir meslek takip olunacağı zan olunsun, erkeklerin sırf erkeklik, hayatta sırf erkeklerin mücadelede bulunması maksatları hatıra kalsın. Hayır! Erkekler Dünyası, bu takım fikir ve itikadı takip etmez ve etmeyecektir." ${ }^{15}$ Kadın haklarının müdafaası gazetenin en ayırt edici niteliğini oluşturmaktadır. Bu konuda yazıda, kadınların haklı mücadelesinin yanında olacaklarını, kadınların üzerinde kurulmak istenen tahakkümlere karşı direnip, cahil tabakanın düşüncelerini dönüştürmeye çalı̧acaklarını dile getirirler. ${ }^{16}$ Fakat böyle bir gazeteye ihtiyaç duymalarının sebeplerinden birinin de dönemin kadın yazar ve aydınlarının, rahatlıkla bahsedemedikleri bir takım özel durumların ve meselelerin varlığı olduğunu ifade etmektedir.

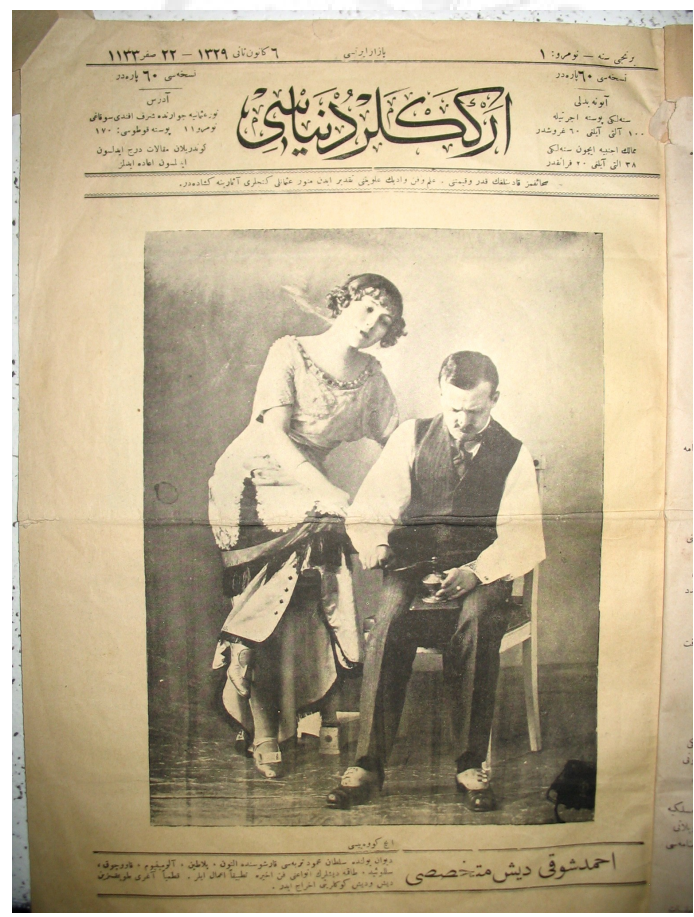

Erkekler Dünyası (19 Ocak 1913): Kapak

Mevlanzade Rıfat, kadınlar için daha mahrem sayılan bu konularda erkek penceresinden bakma imkânı yaratmayı bu gazete vesilesiyle sağlamayı düşünmüştür. Bu durumu “ Kadınlar Dünyası, intişar ediyor, hem de kâmil muvaffakiyetle... Kadınlar Dünyası kadınların muhtaç oldukları hayatın, hürriyetin istihsaline çalışıyor. Fakat bazı misal, içtimaiye vardır ki Kadınlar Dünyası'nın muhterem muharireleri [yazarları] o meseleleri 
tamamıyla serbest olarak teşrih [açma] edemiyorlar. Serbest kalem yürütemiyorlar. Nezaket seviyeleri icabı olarak söyleyemiyorlar. Erkekler Dünyası, kadınların bu ihtiyacını da düşünecek ve münevver tabakanın mezahiretiyle meşgalelerini halle muvaffak olacaktır." ${ }^{17}$ şeklinde ifade etmiştir. Mevlanzade Rıfat kadınların Osmanlı toplumsal hayatında, üzerine gidemediği veya rahatlıkla bahsedemediği meselelerde erkekler olarak rol üstleneceklerinden bahseder. Erkekler Dünyası olarak, erkeklerin gözüyle görülmesi ve irdelenmesi gereken kadın meselelerini, kadınlar lehine görmeye çalışacaklarını vurgulamaktadır.

Mevlanzade Rıfat Bey, dönemin feminist gazeteleriyle de ilgili olan bir Osmanlı aydınıdır. Kadın yazınında çok önemli bir yere sahip olan ve Osmanlı kadın hareketinde etkili olmuş "Kadınlar Dünyası" gazetesinin çıkarılması için gazetenin kurucusu olan eşi Ulviye Mevlan Hanım’a fikir verir. Kadınların hak ve hukuk mücadelesine duyarlı olan Mevlanzade Rıfat, Kadınlar Dünyası ve Erkekler Dünyası arasında bir kaynaşmayı sağlayarak bu yolda bir insanlık dünyası oluşturmanın peşindedir. Anlaşılıyor ki erkek ile kadın'ın birbirine indirgenemez farklılıklar arz ettiği düşüncesini -radikal düalizmi- Mevlanzade Rıfat, şiddetle eleştirmektedir. Kadın ve erkeğin ortak dünyasını insanlar dünyası olarak tasarlayan M. Rıfat, amacının da zaten bu tarz bir kültürel ve fikri dünyayı, toplumsal anlamda yaratmak olduğunu dile getirir. Böyle bir fikri dünyadan kasıt, tüm tikel farklılıklardan arınmış olan ve tümel ortaklıkları ifade eden bir "İnsanlık Dünyası"dır. ${ }^{10}$ Öte yandan, Mevlanzade Rıfat, böyle bir ortak dünyanın yaratılabilmesinin, ancak ve ancak hayatın tüm kurumlarında, hayatın her kulvarında kadın ile erkeğin aynı kültürel ve siyasal olanaklarından; aynı özgürlük haklarından eşit bir şekilde faydalanması suretiyle mümkün olabileceğini söylemektedir: "Bunun için de kadın, erkek bir seviyede olması, her bir umur ve hususta müşterek bulunması, iktiza eder. İşte bu maksadın temini için bütün kuvvetimizle çalışacağız. Ümit ederiz ki tabaka-i münevvere; gençlik bize daima müzahir bulunacaktır" ${ }^{11}$ Erkekler Dünyası dergisinin, kadın erkek eşitliğinden ödün verilemeyeceğine ilişkin tutumunu, aile hayatı ile cemiyet hayatı arasındaki büyük uçurumu ortadan kaldırmanın ancak bu yolla mümkün olabileceğine ilişkin inançlarına dayandırmak pek mümkün. Dergide, kadınlar ile erkekleri eşit irfan ile donatma amacında olduklarını ve bunun için de toplumsal mücadelelerinden ödün vermeyeceklerini dile getirirler. ${ }^{18}$

Kadın sorunu yalnızca Osmanlıda değil dünyanın her yerinde temel bir toplumsal sorun olagelmiştir. Bu sorunlarda erkeklerin de dayanışma içinde olduğu unutulmamalıdır. Kadın hareketlerinin güç kazandığı tüm ülkelerde, kadın hareketlerinin erkekler tarafından da desteklendiğini vurgulayan Rıfat; buna bağlı olarak kadın ve erkeğin birlikte mücadele etmesinin önemine vurgu yapmaktadır. Ona göre toplumsal hayatın ilerlemesi ve insancıl bir hayat anlayışının hüküm sürmesi için kadınların verdiği mücadelede erkeklerin de katkı sunması gerekecektir. Çünkü tek boyutlu; kadınla sınırlı bir kadın hareketinin çok fazla ilerleyemeyeceğini vurgular. ${ }^{12} \mathrm{M}$. Rıfat, kadınların, hayat mücadelesinde önemli bir yer işgal ettiklerini ve gün geçtikçe kadınların toplumsal ilerlemedeki öneminin de buna bağlı olarak görünürlük kazandığını ifade eder. Ayrıca kadınların, toplumsal eleştiride yer almalarının önemine de vurgu yapmaktadır. "Kadına dahi erkekler gibi hukuku yermek erkekler gibi mücadele-i hayatta serbest bırakmak lüzumu idrak edilmiştir. ... Dünyaya bir göz gezdirelim. Bütün insanlar teali yolunu tutmuş ilerliyorlar. Hatta dikkat edilirse kadınların bu tealide daha ziyade muvaffak oldukları, daha ziyade terakki ettikleri, terakki etmek istidatını hazırladıkları görülür. Şu son zamanlarda tecellileri harikulade bir dereceye vardı. Anlamalıyız ki bizim şimdiye kadar kadınlık hakkında düşüncelerimiz, tatbik ve icra ettiklerimiz gayet yanlış şiddetler, gayet makul tazyiklerdir."13 Her şeyden önce Osmanlıda da erkeklerin dünyası kamusal iken kadınların dünyası özeli temsil etmekteydi. Kadınlık, mahremdi ve ailenin içinde yer alıyordu. Hareket alanı daraltılan ve eve mahkûm edilen kadınlar, dar bir evrenin içine sıkıştırılmıştı. $\mathrm{Bu}$ nedenle de kadınların, toplumsal yaşamdaki rolü önemli ölçüde sınırlanmış ve toplumsal üretimin dışında tutulmuşlardı. Mevlanzade Rıfat, Osmanlı kadınlarının büyük çoğunluğunun kamusal alandan soyut yaşamaya mecbur bırakıldığını ve hâkim kültürel ve hukuki hayatın egemenliğinden dolayı baskı altında bulunduklarını ifade etmiştir. Batıda kadınların içtimai hayatta çok çok ileride olduklarına ve her alanda erkeklerle yarışır seviyeye ulaştıklarına değinmektedir. Lakin Osmanlı kadınının, hak etmediği şartlarda yaşadığını, bu durum ise

\footnotetext{
10 "Hulasa maksadımız kadınlar dünyasıyla erkekler dünyasını tedrici olmakla birebir seri adımlarla birbirlerine takip ederek İnsanlık Dünyası'nı vücuda getirmektir. Biz dünyada yalnız bir ‘İnsanlık Dünyası' görmek isteriz.” “İki söz,” Erkekler Dünyası 1, 6 Kanun-i Sani 1329 (19 Aralık 1914), 2.

11 "İki söz," Erkekler Dünyası 1, 6 Kanun-i Sani 1329 (19 Aralık 1914), 2.

12 "Bugün dünyanın her tarafindan, hatta Çin'de, Japonya'da bile vucud-u ailenin, vucud-u ilmiyenin, velhasıl ademiyet ve insaniyetin tek bir ayakla/kadınla tealiye doğru yürüyemeyeceği anlaşılmıştır.” “İki söz,” Erkekler Dünyası 1, 6 Kanun-i Sani 1329 (19 Aralık 1914), 2.

13 “İki söz," Erkekler Dünyası 1, 6 Kanun-i Sani 1329 (19 Aralık 1914), 2.
} 
erkekler ve millet adına bir utanç teşkil ettiğini dile getirmektedir: "milel saire kadınları hayatta erkeklerle rekabet edecek bir tarzda ilerlemelerine mukabil, biz kadınlarımızı durduruyor ve hapis ederek atalete mahkûm ediyoruz. Artık anlamalıyız ki bu bize pek ayıptır." 19

Mevlanzade Rıfat, toplumda kadınların hak ettikleri konuma ulaşmalarını çok önemsiyordu. Birey olarak kadınların, toplumsal rollerini rahat ve özgür bir şekilde tesis edebilecek aşamaya gelebilmelerini, "millet olarak ve insaniyet" açısından ne kadar ilerlediğimizin göstergesi olacağını dile getirir. Ona göre kadınlar, hayatın her alanına eşit bir şekilde katılma olanaklarına ulaştıklarında ve muasır medeniyet -rasyonel aydınlanma- seviyesine ulaştıkları zaman o toplum gerçekten ileri bir toplum olacaktır. ${ }^{20}$ Rıfat, Osmanlı kadın sorununda, tek çözümün kadın ve erkeğin sosyo-kültürel ve siyasal dayanışmasından geçtiğine inanır. Kadınların erkeklerin desteğiyle daha kolay yükseleceğini düşünür. Hayatı birlikte ve eşitlikçi bir hukuk ile omuzlamakla müreffeh olunacağını ifade etmektedir: "Emin olalım: kadın ve erkek, kadın ve erkeğin tabaka-i münevveresi el ele vererek çalışırsa memleketimizin muhtaç olduğu inklab fikri ve içtimaiye kolaylıkla vucuda getirilir..." ${ }^{21}$ Sonuçta, ikincil bir kadere terk edilmiş Osmanlı kadınının sosyal hayattaki değeri ve yerinin yükseltilmesi gerektiğini dile getirir. Aksi takdirde toplumun ilerlemesini olanaklı kılan diğer ayağının eksik olacağına işaret eder. Kadının yükselmesi ile ulusun yükselmesi arasında zorunlu bir ilişki olduğunu ifade eder.

\section{Evlilik ve Aile Kurumu}

Osmanlı kadın hareketinin en önemli taleplerinden biri aile kurumu ve evlilik akdinin yeniden değerlendirilmesi, incelenmesi gerektiğidir. ${ }^{14} \mathrm{Bu}$ talep kadın hareketine destek veren erkek aydınlarca da dillendirilir. Aile kurumunun/yapısının derinlikli bir şekilde, eleştirel bir incelemeye tabi tutmak gerektiğini söyleyen Mevlanzade Rıfat, aynı zamanda aile kurumunun, insan ve toplum hayatının en önemli kurumlarından biri olduğunu dile getirir. Aile hayatının Osmanlıda çok iç açıcı bir gelişme içinde olmadığını ve geleneksel niteliğinin yeterince incelenmediğine vurgu yapar: "Hiç şüphe yok ki hayat-1 beşeriyede, hayat-1 ferdiyede en mühim mesele aile teşkilatıdır"15 bu nedenle yeni/modern ailenin kurulamadığını söyler. Evliliklerin çoğunlukla görücü usulüyle yapıldığı Osmanlı toplumunda, görücü usulünün belirgin bir şekilde meşrutiyetle birlikte sorgulandığını görüyoruz. Mutlu bir hayatın ancak birbirini kendi iradeleriyle tercih eden iki insanın birlikteliğiyle mümkün olabileceği fikri etkili olmaya başlar. Hatta mutlu evliliklerin yapılması için okullarda izdivaç derslerinin konulması dahi dönemin tartışma konularından birini teşkil eder. ${ }^{16}$ Mevlanzade Rıfat Osmanlı yazınında, evlilik gibi aile kurumunun da yeteri kadar incelenmediğini ve bu durumun büyük bir eksiklik ifade ettiğini yazılarında vurgulamıştır. Kaldı ki Osmanlı toplumunun, aile kurumu açısından sefil bir durumda olduğunu belirtir. Buradaki sefaletten kastı aileyi oluşturan fertlerin rollerindeki geleneksel durum ve aile kurumunun görücü usulüyle kuruluşudur. ${ }^{22}$ Aile kurumunun sağlam temellere dayanmamasını, evliliklerin çoğunlukla görücü usulüyle gerçekleşmesine bağlıyor. Birbirini tanımadan körü körüne yapılan evliliğin de sonuçta mutluluk getirmesi de düşünülemez demektedir: "Cihan-1 medeniyette aile teşkilatı hususunda mahtaf kaideler, metnu-i asıllar veza/tespit edilmiştir ki beşeriyeti saadete doğru ve tabii yollarla sevk ediyor. İzdivacı simsarlar vasıtasıyla akit ettirmek, birbirini hiç görmeyen tanımayan iki vücudu körü körüne birleştirmek öteden beri bizde cari olan bir usulü izdivaçtır. Bu usul ile saadetli bir aile teşkil edemiyor ve edemez... Bunu artık bilmek ve teslim etmek lazımdır"23. Aile kurumunun, geleneklerin zoruyla değil, sevgiye dayalı özgür iradeyle birbirini seçen iki kişinin kararıyla kurulmasını savunmasıyla Mevlanzade Rıfat'ın modernleşme taraftarı olduğu söylenebilir. Çünkü modernleşme sürecinin önemli taleplerinden biri de sevgiye dayalı bir evlilik ve çekirdek aile talebi olmuştur ${ }^{24}$ Kişiler arası duygusal ve rasyonel anlaşmaya dayanan birliktelik olan evliliğin, aynı zamanda herhangi bir duygusal ve zihinsel paylaşım olmadan gerçekleştiğinde de çok sorunlu olacağına inanmaktadır. Görücüler aracılığıyla kişinin, aşığını -evleneceği kişiyi- tanımasının ve sevmesinin problemli olacağını, "İzdivaçta en büyük rolü oynayacak hisdir, fikirdir, mizaçtır... Derece-i saniyede servet, camu mensub gibi maddi muvakkat şeylerdir... Hisler fikirler mizaçlar, görücüler vasıtasıyla anlaşılamaz tayin edilmez." 25 Sözleriyle dile getirir. Kadın ve erkeğin kuracağı hayat, birbirlerini tanımaktan geçer. Evlilik öncesi tanışmanın ve hatta flörtün gereğine değinen Mevlanzade Rıfat, bu sürecin daha da uzun tutulmasının iki taraf için de daha faydalı olacağını savunur: "Aile teşkili istidad-ı tabbiyesine gelen iki vücud; erkek, kadın, bir surette terbiye-i

\footnotetext{
${ }^{14}$ Aliye Cevat. "Her şeyden önce kavanin-i aileye, cihet-i meşrua-i müteşekkilesini tedkik ve tetebbu edelim," Kadınlar Dünyast 40, 13 Mayıs 1329 [1912].

15“"Mesut Bir Aile Nasıl Teşekkül Eder?,” Erkekler Dünyası 1, 5-6.

${ }^{16}$ Çakır. Osmanlı kadın hareketi, 202
} 
içtimaiye dairesinde birbirini görmeli, konuşmalı... Hatta görüp konuşmakta bir süre devam edebilmeli... Zira zevc ve zevce, birbirini hissen, fikren, mizacen tanımadıkça mesut bir aile teşkil edemezler. Buna artık insaf ile iman etmeli..." ${ }^{26}$ Kadın-erkek ilişkilerinin geleneksellikten ve hâkim geleneksel ahlakın baskısından kurtarmak amacıyla yazılar yazan Mevlanzade Rıfat, dönemin kadın hareketini de destekler. Erkekler Dünyası dergisi, görücü usulüyle kurulan evliliklere alternatif olması amacıyla, karşılıklı ve gönül rızasına dayanan birlikteliklerle ilgili bazı resimleri de dergide yayınlamıştır. Bu konuda, "Mesut bir aile teşkili safahatını meviser bir surette gösterebilmiş olmak gayesi ile atideki resimleri vezai [yayınlamak] ettik"27 denilmektedir. Ayrıca Erkekler Dünyası dergisinde kullanılan resimlerin, meşrutiyet sonrasında arzu edilen kadın erkek ilişkileri hakkında da önemli fikirler verdiği söylenebilir. Dergide kullanılan resimlerde batılı yüzlerin varlığı, Osmanlı basınında kişisel ilişkilere dair, yerli yüzleri kullanmanın hala hoş karşılanmadığını ve toplumsal bakışın, yerli kareleri normal karşılayacak düzeyde olgunlaşmadığını göstermektedir.

\section{Resimlerle Kurgulanan Mesut "Dünya Evi”}

Osmanlı toplumunun en güçlü kurumlarından biri aile kurumuydu. Aile kurumu meşrutiyetle birlikte küçülmüş ve de değişmiş olsa da bazı karakteristik niteliklerini sürdürmüştür. $\mathrm{Bu}$ değişen nitelik modernleşen Türkiye'de; baba otoritesinden uzak münevver erkeklerin kendilerine irfanen denk oldukları cumhuriyet kadınlarıyla kurdukları aile biçemiyle sürdürülmüştür. Yani Osmanlıdan modern Türkiye’ ye, bazı faklılıklarla da olsa ailenin korunduğunu, aile kurmanın yükselen değer olduğunu unutmayalım. Meşrutiyetle birlikte gelişen modern bakış açılarının sonucu olarak şekillenen bu ailenin en büyük özelliği, iki tarafın da gönül rızasıyla kabul ettiği ilişkinin sonucunda kurulan bir aile olmasıydı. Bu ideal aile, Erkekler Dünyası dergisinde de resimlerle kurgulanan bir aile tarifidir. Belirtilen aile her şeyden önce sevgiye, aşka dayanmak zorundadır (Resim:1):

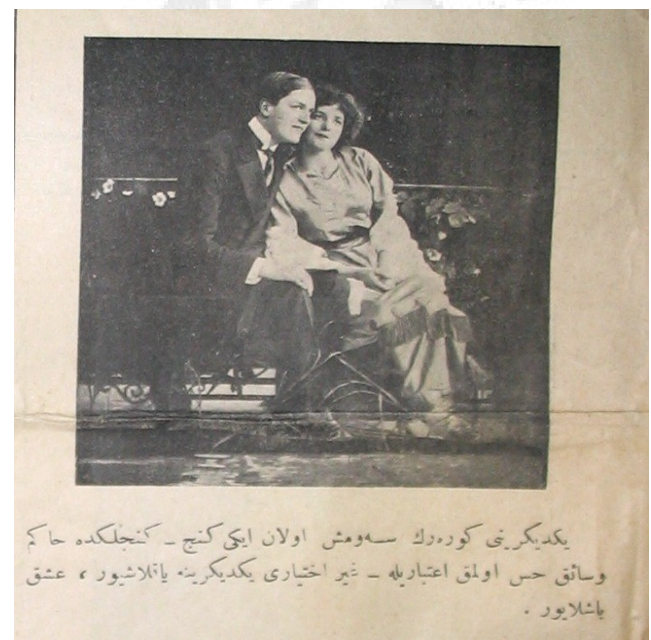

"Birbirini görerek sevmiş olan iki genç -gençlerde hâkim vesaik his olmak itibariyle- gayrı ihtiyari birbirlerine yaklaşıyor ve aşk başlıyor"

(Resim:1)

Görücü usulüne dayanarak yapılan izdivaçların geleneksel kuruluşunu eleştiren Mevlanzade Rıfat, gönül rızasına dayanan birlikteliklerin aynı zamanda uygar olmanın önemli göstergelerinden biri olduğunu ifade etmektedir. Ayrıca ailede kadın erkek ilişkilerinde tatlı dargınlıkların ve sorunların da olabileceğini ama gönüllü ve paylaşarak evlenenlerin bu sorunları daha kolay atlattıklarını dile getiriyor (resim:2): 


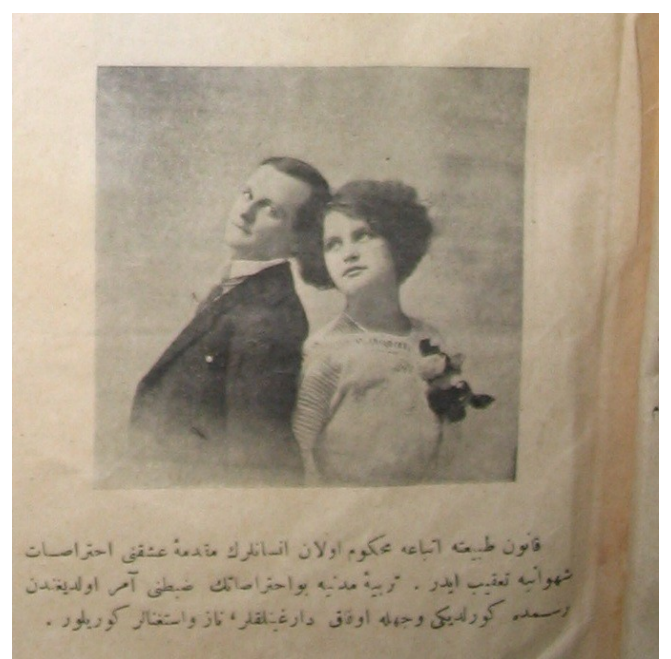

"Kanun-u tabiata itibağa mahkûm olan insanların mukaddime-i Aşkını ihtirasat-ı şehvaniye takip eder. Terbiye-i medeniye ihtirasatın sebatını emir olduğundan resimde görüldüğü gibi ufak dargınlıklar naz ve istisnalar görülür" (Resim:2)

Aslında bu bakış açısı (Resim:2'deki), çoğu kez ataerkil söylemin de ideolojik stratejisi olabilmektedir. Özellikle şiddetli geçimsizlik sürecinde, kadınlar boşanmak istediklerinde karşılaştıkları muhafazakâr ve erkek egemen bir kültürel tutum, bu durumu yeteri kadar kanıtlamaktadır. Örneğin, bir kadın boşanmak istediğinde yakın çevresinden durumu hoş görmesi öğütlenir. Öte yandan bir kadına boşanma başvurusu sırasında, emniyette ilgili memurun dillendirdiği "evliliktir bu canım, bazen kavgalar olur, siz de biraz hoş görün" gibi söylemler, her koşulda kadının üzerinden aile bekasının -tabiî ki sistemin ve kadının edilgenliğinin- fetişleştirildiğinin gösterir. Lakin Mevlanzade'nin de içinde değerlendirilebileceği meşrutiyet sonrasındaki feminist tartışmalarda ailenin, genellikle kurumsal olarak bir iktidar alanı olarak değerlendirilmediğini/tartışılmadığını görüyoruz. Genellikle, ailenin kurumsal olarak yadsınmadığını sadece nasıl olması gerektiği ve ne şekilde yapılandırılması gerektiği tartışılmıştır. Bu nedenle de "Erkekler Dünyası"nda evlilik ile ilgili sorunların sebat ve medeniyet çerçevesinde çözülebileceğine dair ifadeleri, kurumsal olarak aile fetişizminin aksine; aile kuranları rasyonel ilişkilere özendirme çabası olarak okuyabiliriz.

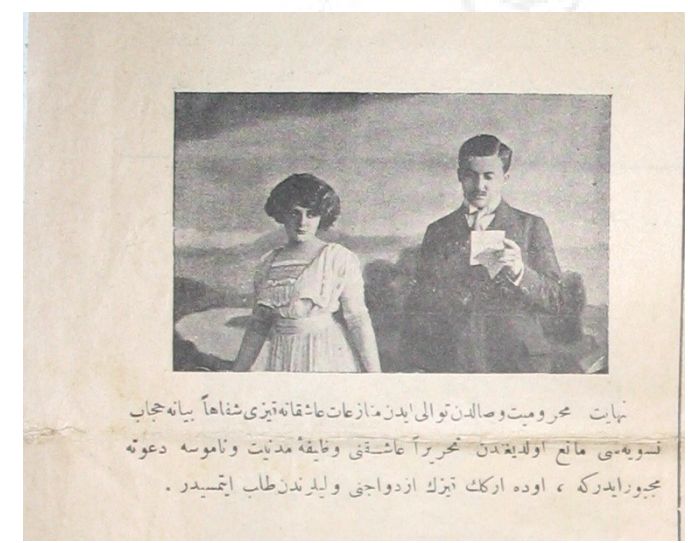

"Nihayet mahrumiyet vesalden tevali eden münazaat-1 aşkane, kızı şifahen beyana hicab neviyesi olduğundan tehriren aşkını vezaife-i medeniyet ve namusa davete mecbur eder ki o da erkek kızın izdivacını velilerinden talep etmesidir"

( Resim:3) 
Görüldüğü gibi (Resim:3) her şeye rağmen evlenecek kişilerin, velilerinden izin alması gerektiğine işaret eden bir tutum söz konusu. Aslında bu tutum günümüzde de hala geçerliliğini korumaktadır. Resimde, iki kişinin bir yandan medeniyetin gereği gibi birbirleriyle serbest görüşebilmeleri gerektiği vurgulanırken öte yandan bu ilişkinin, medeni bir sorumluluğun gereği olarak bir an önce velilerinin de onayını alarak evlilikle sonuçlanması gereğine vurgu yapılmaktadır. Dolayısıyla meşrutiyetle birlikte görülüyor ki, evlilik öncesinde flörtün gerekli olduğu anlayışının, ancak bu süre fazla uzamadığı takdirde hoş karşılanmaktaydı.

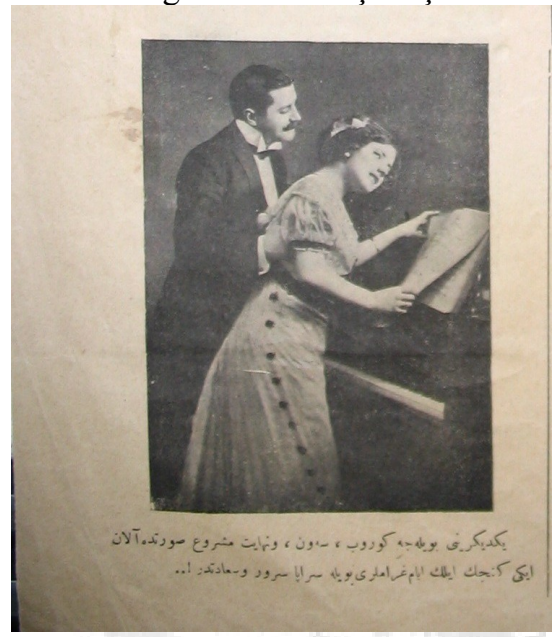

"Yekdiğerini böylece görüp seven, nihayet meşrû surette olan iki gencin ilk yam gramları böyle serapa server ve saadettir"

(Resim:4)

Meşrutiyet dönemi diğer kadın yazınında olduğu gibi, Erkekler Dünyası dergisi de özellikle görücü evliliklere karşı, sevgiye ve gönül rızasına dayanan ilişkileri öne çıkarır. Ve belki de en önemli nokta, aile kurmanın hem toplumsal yaşam ve ahlakın bekası için, hem de mutlu olmanın en önemli seçeneği olarak öne çıkarılmasıydı. Tabiî ki bu aile, biraz da büyük baba otoritesinden yalıtılmış bir çekirdek ailedir. Diğer yandan derginin, ailevi sorunların çözümü konusunda yenilikçi bir açılım gösterirken, geleneksel bakış açısının bazı kalıntılarından hala kurtulamadığını da söylemek gerekir.

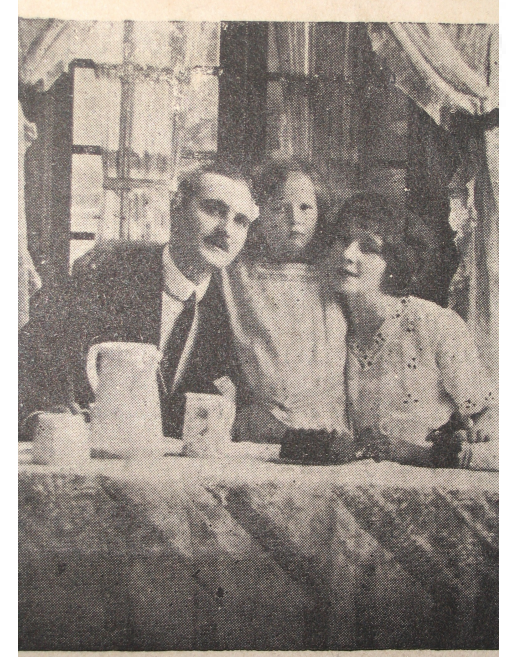

“Aşk ihtimal ki eski şiddeti muhafaza etmiyor. Fakat araya giren şu mini mini öyle bir rabıtadır ki cesaret-i sevdayı, mesut bir hayatı aileye kalb ediyor"

(Resim:5) 
Çünkü evli çiftler arasında doğan anlaşmazlık, geçimsizliklerin ya da ilişkideki kötü gidişatın çocuk sahibi olmakla birlikte aşılabileceği vurgulanmaktadır (Resim:5). Çocuğun, ayrılığa ve kopuşa doğru giden bir evlilikte raptiye görevi gördüğüne işaret edilmektedir. Aslında kadınların geleneksel konumlarında birçok açıdan modernleşmeden yana görüş beyan etmiş Mevlanzade Rıfat gene de klasik ataerkil bakışın etkisinden tam olarak kurtulamamıştır. En açık durumda, ailenin güç kazanmasını ve karı kocanın birbirleriyle olan sorunlarını doğacak olan çocuklarla aşabileceğini düşünmesi bu durumu açıkça gösterir. Çünkü ataerkil kültürel kodlar da bu ve buna benzer anlayışları içinde barındırmıştır.

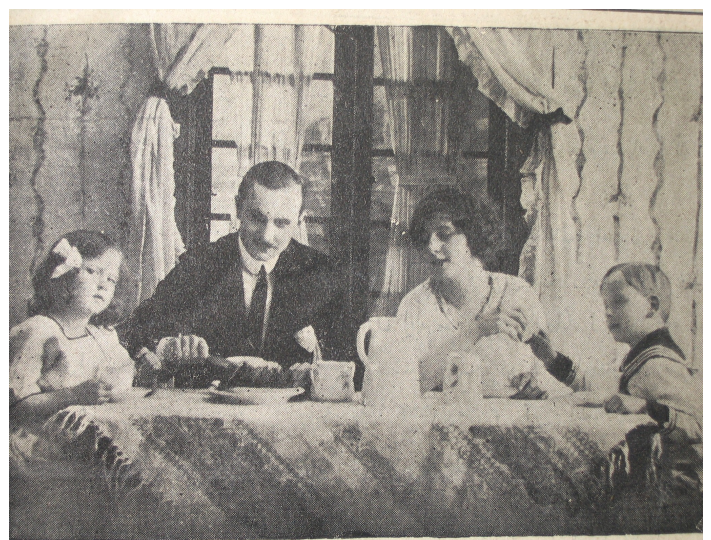

"Bunu takip eden şu ikinci nihal-1 ömür, zevc ile zevceden bu iki nev-i nihalın saadetini temin ailesini bekliyordu. Böyle mesut ailenin mefkuresinde dedi kodular, hırçınlıklar kalmaz, görülmez, saadet ömrün nihayetine kadar devam eder!...”(Resim:6)

Anlaşmazlık yaşayan ve belki de ayrılması gereken 'karı kocanın' durumuyla ilgili olarak söylenen bu klişe bakış açısı günümüzde de yaygındır. Yani Mevlanzade Rıfat da "Hatta çocuk sayısı artıkça karı-kocanın daha mesut bir birliktelik kurdukları ve ömrün sonuna kadar saadetli bir sona varacakları belirtilmektedir." Sözleriyle ailede doğan her sorunun doğacak yeni çocukla aşılabileceğini söyleyerek Osmanlı aydınının da bir anlamda eksik duyarlılığını yansıtmaktadır.(Resim:6). Çünkü bu tür ailevi sorunlarda boşanma da bir çözüm olarak sunulabilseydi o zaman bir ataerkil açılımsızlık söz konusu olmayabilirdi. Bu durum da bir seçenek olabilirdi.

\section{Sonuç}

Kadın sorunu, aile ve evlilik gibi pek çok konu meşrutiyet ve sonrasında Osmanlı aydınları tarafından çokça tartışılmıştır. Görüldüğü gibi bu dönemin tartışmalarına, çıkardığı gazete aracılığıyla önemli katkılar sunmuş olan Mevlanzade Rıfat'ın; görüşlerini “Erkekler Dünyası” gazetesinin var olan tek sayısı ile sınırlı kalarak ele aldık. Sonuç olarak Osmanlı kadın hareketinin etkin kadınlarından biri olan Ulviye Mevlan'ın faaliyetlerinin yakın destekçisi olarak Mevlanzade Rıfat, önemli bir feminist olarak karşımıza çıkmaktadır. Mevlanzade Rıfat, meşrutiyet sonrasında kendini açığa çıkaran ve klasik kurumların değişmesi gerektiği yönünde çaba sarf eden Osmanlı aydınlarını da temsil eden bir portredir. Bir yandan Osmanlının aile kurumunda yenilikler yapmasından yana tutum sergilerken aynı zamanda hala annelik veya anneliğin yüce bir vazife olarak övdügünü görüyoruz. Batı kültürünü hazmetme ve sindirme sürecindeki sıkıntılarla beraber farklılaşan bu tutumlar, aslında dönemin aydın çelişkilerinin bir yansımasıdır. Fakat netice itibariyle Mevlanzade Rıfat, dönemin erkek aydınlarının açılımsızlığına düşmüş ve bazı geleneksel kadın rollerini korumaktan yana fikirler beyan etmiş olsa da Osmanlı feminist yazınına yaptığı önemli katkılarıyla öne çıkan şahsiyetlerden biridir. 
${ }^{1}$ Kadın meselelerine dair yazdıkları yazılar ve yayınladıkları bazı alışmalarıyla kadın Hareketine katkı sunan diğer bazı aydınların başında Abdullah Cevdet, Rıza Tevfik, Selahattin Asım, Ahmet Cevat, Celal Nuri, Ziya Gökalp, Baha Tevfik gibi isimler gelmektedir.

${ }^{2}$ Nuriye Ulviye Mevlan (Civelek), 1893-1964 yılları arasında yaşamış ve Osmanlı kadın hareketinin önemli portrelerinden biridir.

${ }^{3}$ Bunlar arasında ise Mevlânzâde Rıfat ve Ahmet Süreyya Bedirhan gösterilebilir.

${ }^{4}$ Ali Birinci. 31 Mart Vakıa'sının Bir Yorumu, Türkler-Osmanlı ( Ansiklopedi) 13. cilt. S: 197

${ }^{5}$ Rohat Alakom. Şerif Paşa: Bir Kürt Diplomatının Firtınalı Yılları. Avesta, 1998 İstanbul.

${ }^{6}$ Mevlanzade Rifat. 31 Mart bir İhtilalin Hikâyesi, İstanbul: Pınar yayınları, 1996.

${ }^{7}$ Mevlanzade Rıfat'ın Anılarl, 91.

${ }^{8}$ Rohat Alakom. Şerif Paşa: Bir Kürt Diplomatının Fırtınalı Yılları. İstanbul: Avesta, 1998.

${ }^{9}$ Bkz: Alakom, Şerif Paşa, 76 ve Mevlanzade Rıfat'ın Anıları, 91.

${ }^{10}$ Milli mücadele döneminde Atatürk'ün azınlık politikalarını eleştirdiği için ve Atatürk'e hakaret ettiği iddiasıyla 150'likler listesine dâhil edilir ve sürgüne gönderilir. Suriye'deki sürgün yılları 1930 da ölümüyle son bulur.

${ }^{11}$ Rifat, Mevlanzade. 31 Mart bir ihtilalin hikâyesi. Pınar Yayınları. İstanbul 1996

12 “İki söz," Erkekler Dünyası 1, 6 Kanun-i Sani 1329 (19 Aralık 1914), 2.

13 "İki söz," Erkekler Dünyası 1, 6 Kanun-i Sani 1329 (19 Aralık 1914), 2.

${ }^{14}$ Bir dergi olarak kabul edeceğiz. Çünkü Yayınlanma süresi hakkında bir bilgi verilmemiştir. Ve dönemin gazetelerinden daha küçük ebatlarda yayınlanmıştır.

15 “İki söz,” Erkekler Dünyası 1, 6 Kanun-i Sani 1329 (19 Aralık 1914), 2.

16 “....Erkekler Dünyası'nın takip edeceği gayelerin en büyüğünü kadınlık meselesi teşkil edecektir. ....Erkekler Dünyası beyhude tahakkümlere, vahi gururlara kapılan tabaka-i cahilenin efkar ve dimağını tenevir ve terbiyeye çalışarak, hukuk-u nisvanı dahi daha vasi mukayesede müdafaa edecektir." "İki söz,” Erkekler Dünyası 1, 6 Kanun-i Sani 1329 (19 Aralık 1914), 2.

17 “İki söz," Erkekler Dünyası 1, 6 Kanun-i Sani 1329 (19 Aralık 1914), 2.

18 "Erkekler Dünyası hayatta kadınlardan ayrılmayacaktır. Kadınlarla erkekleri aynı seviyede aynı irfanda aynı hayat ve hürriyette yaşatmağa paylaşarak aile hayatıyla cemiyet hayatını muntazam bir surette kalbi gayret edecektir.”, “İki söz,” Erkekler Dünyası 1, 6 Kanun-i Sani 1329 (19 Aralık 1914), 2.

19 “İki söz,” Erkekler Dünyası 1, 6 Kanun-i Sani 1329 (19 Aralık 1914), 2.

20 "Pekâlâ iman ederiz ki kadınlara hürmet ve mezahiret, vacibe-i ademiyettir. Kadın bir hayat içtimaiyede tealisi en mühim bir ihtiyaç olan bir vücuttur. Ne vakit kadını teali ettirirsen mesaiyemize şerik [ortak] eylersek o zaman milletimizin tealisi ihtiyaçları, vasitaları temin edilir.", “İki söz,” Erkekler Dünyası 1, 6 Kanun-i Sani 1329 (19 Aralık 1914), 2.

21 "İki söz," Erkekler Dünyası 1, 6 Kanun-i Sani 1329 (19 Aralık 1914), 2.

22 "Hala bize göre biz şarklılara göre, bu mesele ehemmiyetle tetkik ve talkiye şayandır. Çünkü bu hususta biz sefil durumdayız.",

"Mesut Bir Aile Nasıl Teşekkül Eder?," Erkekler Dünyası 1, 5-6.

${ }^{23}$ Erkekler Dünyas1, "Mesut Bir Aile Nasıl Teşekkül Eder?," 5-6.

${ }^{24}$ Serpil Sancar Üşür. Türk modernleşmesinin cinsiyet rejimi, Doğu-Batı, 2004.

25 "Mesut Bir Aile Nasıl Teşekkül Eder?," Erkekler Dünyası 1, 5-6.

26 "Mesut Bir Aile Nasıl Teşekkül Eder?," Erkekler Dünyası 1, 5-6.

27 “Mesut Bir Aile Nasıl Teşekkül Eder?," Erkekler Dünyası 1, 5-6.

\section{Kaynaklar}

Alakom, Rohat. Şerif Paşa: Bir Kürt Diplomatının Fırtınalı Yılları. İstanbul: Avesta, 1998.

Aliye Cevat. "Her şeyden önce kavanin-i aileye, cihet-i meşrua-i müteşekkilesini tedkik ve tetebbu edelim,” Kadınlar Dünyası 40, 13 Mayıs 1329 [1912].

Ayda, Adile. Kadın gazetesi. 13 Aralık 1965, 15.

Birinci, Ali. 31 Mart Vakıa'sının Bir Yorumu, Türkler-Osmanlı ( Ansiklopedi) 13. cilt.

Çakır, Serpil . Osmanlı kadın hareketi, İstanbul: Metis Yayınları, 1996.

Mevlanzade Rıfat. 31 Mart bir İhtilalin Hikâyesi, İstanbul: Pınar yayınları, 1996.

Mevlanzade, Rifat. Mevlanzade Rıfat'in Anıları, İstanbul: Arma yayınları, 1992, 11-12.

Ruşen Zeki. “Bizde Hareket-i Nisvan,” Nevsal-i Milli, İstanbul, 346.

Sancar Üşür, Serpil. Türk modernleşmesinin cinsiyet rejimi, Doğu-Batı, 2004.

“İki söz,” Erkekler Dünyası 1, 6 Kanun-i Sani 1329 (19 Aralık 1914), 2. 
“Mesut Bir Aile Nasıl Teşekkül Eder?,” Erkekler Dünyası 1, 5-6. 